Brit. J. Ophthal. (1957) 41, 508.

\title{
CORRESPONDENCE
}

\section{EXTRA-CONJUNCTIVAL ORBITAL IMPLANTS}

\section{To the Editorial Committee of the British JouRnal OF OpHTHALMOLOGY}

SIRS-Having criticized Mr. Nairac's original description of his procedure (Nairac, 1954), on the grounds that implants should be completely buried, and that he had not allowed sufficient time to elapse before reporting his results, I must now hasten to thank him for the detailed way in which he has set out his results to date (Nairac, 1957) and to congratulate him upon the encouraging degree of success which he has so far obtained. At the same time, I do not feel that he is yet in a position to claim that he has disposed of criticisms made by Arruga and by myself. Any incompletely-buried orbital implant violates a biological law, and great caution must be exercised before passing mature judgement upon $\mathrm{Mr}$. Nairac's method. I would say that a minimum of one hundred implants would have to be followed up for a minimum of 5 years before a statistical evaluation and comparison with completely buried implants could usefully be made; of $\mathrm{Mr}$ Nairac's 26 implants, only six have been at risk for as much as 3 to $3 \frac{1}{2}$ years, too few for too short a period to satisfy these requirements.

A further criticism of his method which emerges from a study of his recent paper is the amount of attention required by patients after the original operation. In seven cases, either superior or inferior rectus cut out and had to be re-sutured; granulations or threatened cellulitis or discharge were mentioned in connexion with a further seven cases; and trouble-free progress was maintained in only eleven of the 26 cases. The "morbidity" of these extra-conjunctival implants would therefore seem to be high, although the "mortality" to date is only one in 26 !

With regard to this principle of completely burying an implant, I have to admit that about 3 years ago we commenced the routine use of the Arruga one-pin type of implant (Arruga, 1953; Choyce, 1955). Although the implant is completely buried at the time of operation, after 1 to 2 months the metallic pin works through the overlying Tenon's capsule and conjunctiva, projecting into the socket and articulating directly with a suitable prosthesis. We have inserted thirteen such implants; there have been no complications, no further operations, and no extrusions or removals to date, and the cosmetic results are excellent. We are therefore continuing with this type of implant to the exclusion of others. We hope to publish a more detailed study when a substantial number can be reviewed, and after a 5-year period.

At the same time, I should again like to congratulate Mr. Nairac on his admirable results so far, with particular reference to the eleven cases out of the 26 under the 
age of 20. I look forward to hearing the subsequent fortunes of these cases at a still later date.

\section{Wimpole STREeT, LONDON, W.1. 11 March, 1957.}

Yours faithfully,

D. P. CHOYCE

\section{REFERENCES}

Arruga, H., and Arruga, A. (1953). Arch. Soc. oftal. hisp.-amer., 13, 731.

CHOYCE, D. P. (1955). Fortschr. Augenheilk., 4, 10. (Bibl. ophthal. (Basel), Fasc. 42).

NAIRAC, M. L. (1954). British Journal of Ophthalmology, 38, 378. (1957). Ibid., 41, 182.

\section{BOOK REVIEW}

Developmental Abnormalities of the Eye. By Ida Mann. Second edition, 1957. Pp. 419, 284 figs (66 col.). British Medical Association, London. (90s.)

When Ida Mann's Developmental Abnormalities of the Eye appeared in 1937, the book was hailed as unique, a logical sequel to her Development of the Human Eye which had been published 6 years earlier. The book was a good one, each abnormality was accurately described and pictorially illustrated, and its pathogenesis fully discussed; in such discussions the author, while giving fair credit to the numerous hypotheses associated with the incidence of many conditions, always stated her own views, which were usually based on a profound and almost unrivalled knowledge of ocular embryology and its aberrations, and only very occasionally on feminine intuition. This excellent book has long been out of print and a second edition has now appeared, essentially based on its predecessor, but including the new additions to our knowledge which have accrued in the interim. The book is an excellent one, full of information and sound teaching and fun to read; moreover, the illustrations, many from the author's own hand, are excellent and informative. As a monograph on this subject it is unique in the English language.

\section{BOOKS RECEIVED}

The following books have been received and will be abstracted in Ophthalmic Literature, Volume 11, No. 1:

Emmetropia and its Aberrations. By A. Sorsby, B. Benjamin, J. B. Davey, M. Sheridan, and J. M. Tanner. 1957. Pp. 69, 10 figs, 16 tab., 3 appendices. Medical Research Council Special Report Series, No. 293. H.M.S.O., London.

Modern Problems in Ophthalmology, Vol. 1. Edited by E. B. Strieff and J. Babel. 1957. Pp. 740, 220 figs (inc. 11 pl., 4 col.). Karger, Basel. (Swiss Frs 60.)

\section{NOTES}

\section{INTERNATIONAL COUNCIL OF OPHTHALMOLOGY}

The following were present at the annual meeting held in London at the Royal College of Surgeons on April 10, 1957.

Duke-Elder (President), Berens (Vice-President), Hartmann (Secretary), Amsler (Treasurer).

Alvaro (Brazil), Arruga (Spain), Bietti (Italy), Charamis (Greece), Coppez (Belgium), Franceschetti (Switzerland), Lyle (Great Britain), Marshall (Canada), Palomino Dena (Mexico), Paufique (France), Samuels (U.S.A.), Thiel (Germany), Weve (Holland).

Copper (co-opted Secretary in charge of Index Ophthalmologicus) and François (SecretaryGeneral, XVIII International Congress, Brussels). 